\title{
The Namib Col Current
}

\author{
KEVIN G. SPEER,${ }^{*}$ G. SIEDLER $\dagger$ and L. TALLEY
}

(Received 25 July 1994; in revised form 2 May 1995; accepted 6 July 1995)

\begin{abstract}
Recent measurements indicate the transatlantic extent of the Namib Col Current at depths of $1300-3000 \mathrm{~m}$ near Lat. $22^{\circ} \mathrm{S}$ in the South Atlantic Ocean. This current forms a continuous circulation structure from the Namib Col on the Walvis Ridge to the western trough, though its characteristic change as deep water with varying propertics enters and leaves the current owing to a meridional flow component. Transport estimates from hydrographic sections on the Walvis Ridge and at $15^{\circ} \mathrm{W}$ near the crest of the Mid-Atlantic Ridge indicate a strength of about $3 \times 10^{6} \mathrm{~m}^{3} \mathrm{~s}^{-1}$. The current is part of a larger-scale eastward flow at Lon. $25^{\circ} \mathrm{W}$; transport estimates across the salinity maximum core there show a similar strength. Associated with this high-salinity highoxygen current is a basin-wide front in these properties of varying intensity (weaker in the east) marking the transition to deep water whose North Atlantic characteristics have been partly erased by mixing with Circumpolar Deep Water in the southwest South Atlantic. The water which finally crosses the Walvis Ridge is supplied both by the eastward flow of this (diluted) North Atlantic Deep Water and by a general southeastward interior flow from the northern Angola Basin. Evidence suggests that this deep water continues south in the eastern Cape Basin, leaving the South Atlantic near the African continent.
\end{abstract}

\section{INTRODUCTION}

Outside the equatorial band and the Antarctic Circumpolar Current, only a few cases of concentrated deep zonal interior flow, or deep zonal jets, have been documented (Warren, 1982; Warren and Owens, 1988; Warren and Speer, 1991). Their exact location is evidently an accident of local topography, but their existence is likely to be due to simple large-scale circulation constraints related to upwelling and mass conservation. It is through their influence on property distributions, though, that such flows make themselves apparent. In the South Atlantic Ocean, deep property distributions show patterns suggesting eastward flow near the equator and near $25^{\circ} \mathrm{S}$ (Wüst, 1935; Bainbridge, 1980). Wüst (1935) actually expressed the view that elevated oxygen concentrations in the deep water of the eastern South Atlantic between $20^{\circ} \mathrm{S}$ and $30^{\circ} \mathrm{S}$ were the result of eastward flow. Defant (1941) showed broad eastward flow at $2000 \mathrm{~m}$ depth between $20^{\circ} \mathrm{S}$ and $30^{\circ} \mathrm{S}$. Zhang and Hogg (1992) found a similar flow in their analysis of climatological hydrographic data within a limited region of the Brazil Basin, west of the Mid-Atlantic Ridge $\left(5^{\circ}-26^{\circ} \mathrm{S}, 31^{\circ}-19^{\circ} \mathrm{W}\right)$. Reid (1989), on the other hand. inferred that the deep flow was westward over the latitude range $10-25^{\circ} \mathrm{S}$ west of the ridge, and became eastward only

\footnotetext{
*Corresponding author: K. G. Speer, Laboratoire de Physique des Océans, IFREMER, B.P. 70. 29280) Plouzanć, Francc.

†Institut für Meereskunde, Düsternbrooker Weg 20, 2300 Kiel, Germany.

$¥$ Scripps Institute of Oceanography, La Jolla, CA 92093, U.S.A.
} 
south of $25^{\circ} \mathrm{S}$, forming an anticyclonic circulation in the Brazil Basin and in the northern part of the Argentine Basin. Near $25^{\circ} \mathrm{S}$, his western trough flow was dominantly to the north. On the other side of the Mid-Atlantic Ridge, Reid's (1989) circulation showed eastward flow near $25^{\circ} \mathrm{S}$.

Tsuchiya et al. (1994) emphasized in their analysis of hydrographic data along $25^{\circ} \mathrm{W}$ (west of the ridge) the abrupt shift in the deep vertical oxygen structure from multiple vertical extrema north of $25^{\circ} \mathrm{S}$ to a single oxygen maximum in a deeper layer farther south. The lateral structure of dissolved oxygen concentration and salinity distributions on deep water isopycnals displayed by Reid (1989), and more recently Tsuchiya et al. (1994), shows higher values in the interior of the western basin from roughly $20-30^{\circ} \mathrm{S}$, with maxima near $22^{\circ} \mathrm{S}$. They explained the high oxygen and salinity in the interior as a result of Reid's (1989) deep anticyclonic gyre in the Brazil Basin. However, as Reid (1989) showed mainly a northward flow across these oxygen and salinity maxima, the question of their origin and relation to the gyre remains unclear. Is a simple deformation of the anticyclone adequate to explain the property distributions, and are transport calculations at $25^{\circ} \mathrm{W}$ consistent with such flow?

Warren and Speer (1991) observed an eastward-flowing current near $22^{\circ} \mathrm{S}$ east of the Mid-Atlantic Ridge in the Angola Basin they called the Namib Col Current. They estimated a geostrophic transport to the east of $2.2 \times 10^{6} \mathrm{~m}^{3} \mathrm{~s}^{-1}$ over the depth range $130(1)-3200 \mathrm{~m}$, and described the role of this current in shaping deep eastern South Atlantic property distributions. The current was thought to extend from the Namib Col (a saddle on the Walvis Ridge of depth $3000-3250 \mathrm{~m}$ ) west at least to the Mid-Atlantic Ridge (Fig. 1).

In the course of F.S. Meteor Cruise 15 , nominally along $19^{\circ} \mathrm{S}$, it was possible to occupy a number of stations across the Namib Col on the Walvis Ridge to check for the presence of this current. Another short hydrographic section was occupied at $15^{\circ} \mathrm{W}$, above the western flank of the Mid-Atlantic Ridge. This report is concerned with these and other recent measurements in order to determine the extent and strength of the Namib Col Current located near $21-22^{\circ} \mathrm{S}$. A motivation for further measurement was the apparent dynamical necessity for the pressure anomaly associated with zonal flow, and hence the zonal flow itself, to penetrate west of the Mid-Atlantic Ridge in the absence of a solid barrier there at the depths of the current.

\section{DATA}

Hydrographic measurements come from leg 3 of F.S. Meteor Cruise 15, JanuaryFebruary 1991, and leg 4 of the R.V. Melville HYDROS cxpedition, March-April 1989. Full details of the logistics and operations can be found in Siedler and Zenk (1992) and HYDROS (1992); only a brief summary is given here. A discussion of the full set of properties along the entire $25^{\circ} \mathrm{W}$ HYDROS section may be found in Tsuchiya et al. (1994). Results from the AJAX Expedition (1985) Stas 23-37 near 1-2 $-2^{\circ} \mathrm{E}$ as described by Warren and Speer (1991) are used here as well (see Fig. 1 for station locations).

All hydrographic stations were occupied with a Neil Brown Mark III CTD $\mathrm{O}_{2}$ and 36 bottle rosette for collecting water samples. Each cast extended to within $10-15 \mathrm{~m}$ of the bottom, unless the bottom depth signal was poor, in which case the cast was somewhat shallower. Station spacing averaged $65 \mathrm{~km}(100 \mathrm{~km}$ on the portion of AJAX used here), with higher resolution over steep topography.

Salinity samples were analysed with a Guildline Autosal 8400 A salinometer using 


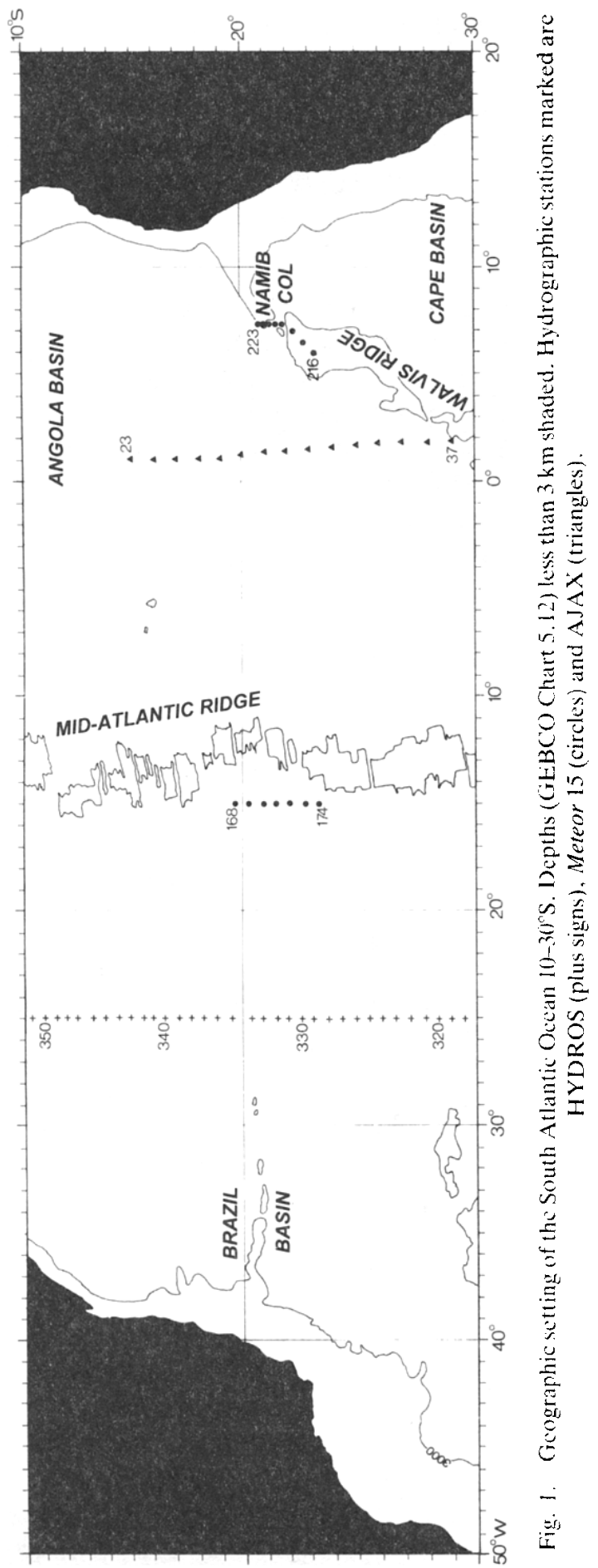


standard seawater batches P112 (Meteor) and P108 (Melville). Oxygen was analysed according to the Winkler-Grasshoff method. Temperature, salinity, pressure and dissolved oxygen measurements are thought to be accurate to $\pm 0.002^{\circ} \mathrm{C}, \pm 0.003 \%$ o, $\pm 3 \mathrm{dbar}$ and $\pm 0.05 \mathrm{ml} \mathrm{l}^{-1}$.

\section{FLOW SCHEMATIC}

Before discussing individual sections, an overview of deep water salinity on an isopycnal surface near $2200 \mathrm{~m}$ depth is provided for reference (Fig. 2). The overall salinity distribution on this surface agrees quite well with the newer data, though some of the structure is lost to smoothing. Arrows representing flow along and across isohalines are displayed as a schematic of flow in the Namib Col Current and nearby currents only; their relation to transport estimates will be discussed in section 5 .

An important observational fact concerning deep water currents is that in contrast to strong thermocline or western boundary currents, properties often evolve significantly along a current. This evolution can be purely advective if water enters the current from one side and leaves it on the other side, after undergoing a displacement within the current.

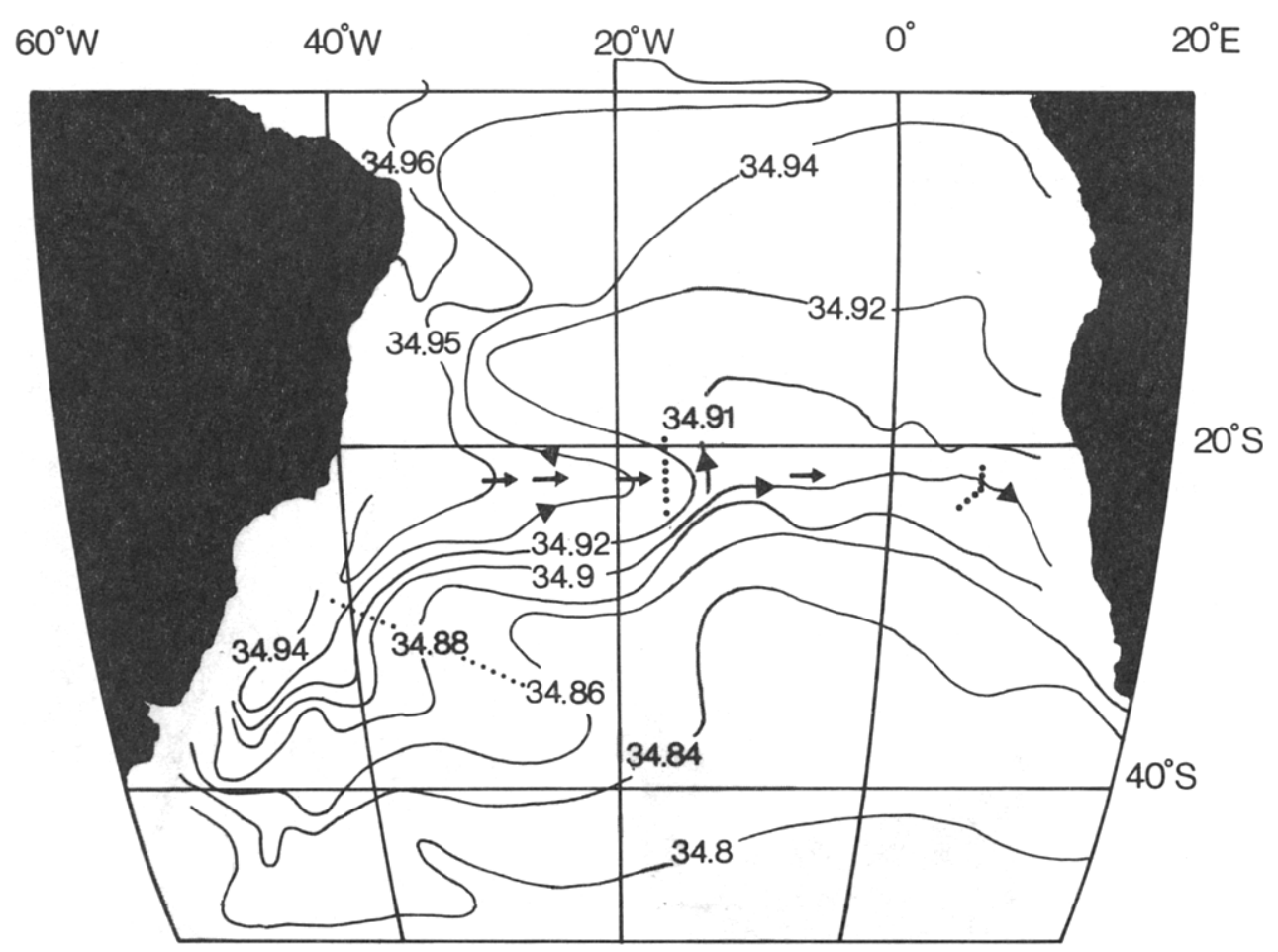

Fig. 2. Distribution of salinity on the isopycnal surface $36.98 \mathrm{~kg} \mathrm{~m}^{-3}$ in potential density anomaly, adapted from Reid (1989). The depth of this surface ranges from $2200 \mathrm{~m}$ in the tropics to $2400 \mathrm{~m}$ near $40^{\circ} \mathrm{S}$. Stations are shown from Meteor cruise 15 at $15^{\circ} \mathrm{W}$ and the Namib Col (larger dots), and a portion of a hydrographic line along the Rio Grande Rise used in transport calculations (dotted line). Arrows indicate schematically the direction of flow based on transport calculations (see text). 
When a range of water types does this the properties of the current can change by substitution. This effect explains the greatest property changes along the Namib Col Current: those across the Mid-Atlantic Ridge, but it also operates all along its length. Lateral and vertical mixing change the propertics of water parcels themselves allowing flow across isopleths. In the flow scheme cross-isohaline flow is admitted, at least in the western trough (see e.g. Zhang and Hogg, 1992), where lateral mixing may be the dominant mixing mechanism in a narrow tracer tongue.

Much like Reid's (1989) circulation for this region, deep water leaves the western boundary south of $20^{\circ} \mathrm{S}$ and moves northeast more or less following isohalines (Fig. 2). Unlike Reid (1989), more water crosses the Mid-Atlantic Ridge before turning north in a current above the eastern flank. Northward flow above the entire eastern flank of the ridge in the depth range $2400-4000 \mathrm{~m}$ was described by Warren and Speer (1991), and thought to be fed by deep water flow from the western boundary in Lats $30-35^{\circ} \mathrm{S}$. They also noted that at $24^{\circ} \mathrm{S}$, the ridge flank current extends to shallower depths as well $(1300-2400 \mathrm{~m})$, whereas at $11^{\circ} \mathrm{S}$, on the contrary, there is southward flow at depths near $2000 \mathrm{~m}$ across the Angola Basin. The salinity distribution (Fig. 2) supports the idea that at depths near $2200 \mathrm{~m}$ the ridge flank current flows north only part way up the basin, that is, up to about $15^{\circ} \mathrm{S}$, before joining a southward interior flow, and that moreover at these shallower depths it is fed by zonal flow in Lats $25-30 \% \mathrm{~S}$ west of the ridge.

This flow is more than a simple deformation of Reid's (1989) anticyclonic gyre, because it implies a net eastward tranport of deep water out of the Brazil Basin and across the MidAtlantic Ridge, whereas his gyre confines (between $10-35^{\circ} \mathrm{S}$ ) deep water to be west of the ridge. However, as Reid (1989) was addressing the circulation of the entire South Atlantic, and not just (schematically) a portion of it, a general similarity to his flow pattern should be emphasized.

\section{PROPERTY DISTRIBUTIONS}

The structure of deep water below $1000 \mathrm{~m}$ depth and above $4000 \mathrm{~m}$ depth is described in the order from west to east using the three meridional profiles of hydrographic properties at $25^{\circ} \mathrm{W}, 15^{\circ} \mathrm{W}$ and across the Namib Col of the Walvis Ridge. Within this depth range three major water masses are usually distinguished: North Atlantic Deep Water, concentrated roughly between $2000 \mathrm{~m}$ and $3000 \mathrm{~m}$ depth, and Upper and Lower Circumpolar Deep Water. The latter two are old, oxygen-depleted, deep water mixtures that enter the South Atlantic through the Drake Passage, with an antarctic component that makes them relatively fresh and nutrient enriched, compared to the deep water from the North Atlantic. The distribution of properties in the North Atlantic Deep Water layer is emphasized, consistent with the outline of flow in the previous section.

\section{1. $25^{\circ} \mathrm{W}$ section}

Dissolved oxygen concentration and salinity at $25^{\circ} \mathrm{W}$ were discussed in detail by Tsuchiya et al. (1994); these properties are displayed here over a reduced latitude range (Fig. 3). The overall vertical structure of the oxygen and salinity maxima between $20^{\circ}$ and $30^{\circ} \mathrm{S}$ changes from a thick layer with a salinity maximum near $2000 \mathrm{~m}$ depth in the north to a thinner, smoother shape in the south with oxygen and salinity maxima closer to $3000 \mathrm{~m}$ depth (Fig. 3; see also Tsuchiya et al., 1994). This front between southern and northern 
(a) HYDROS 4 SALINITY 500

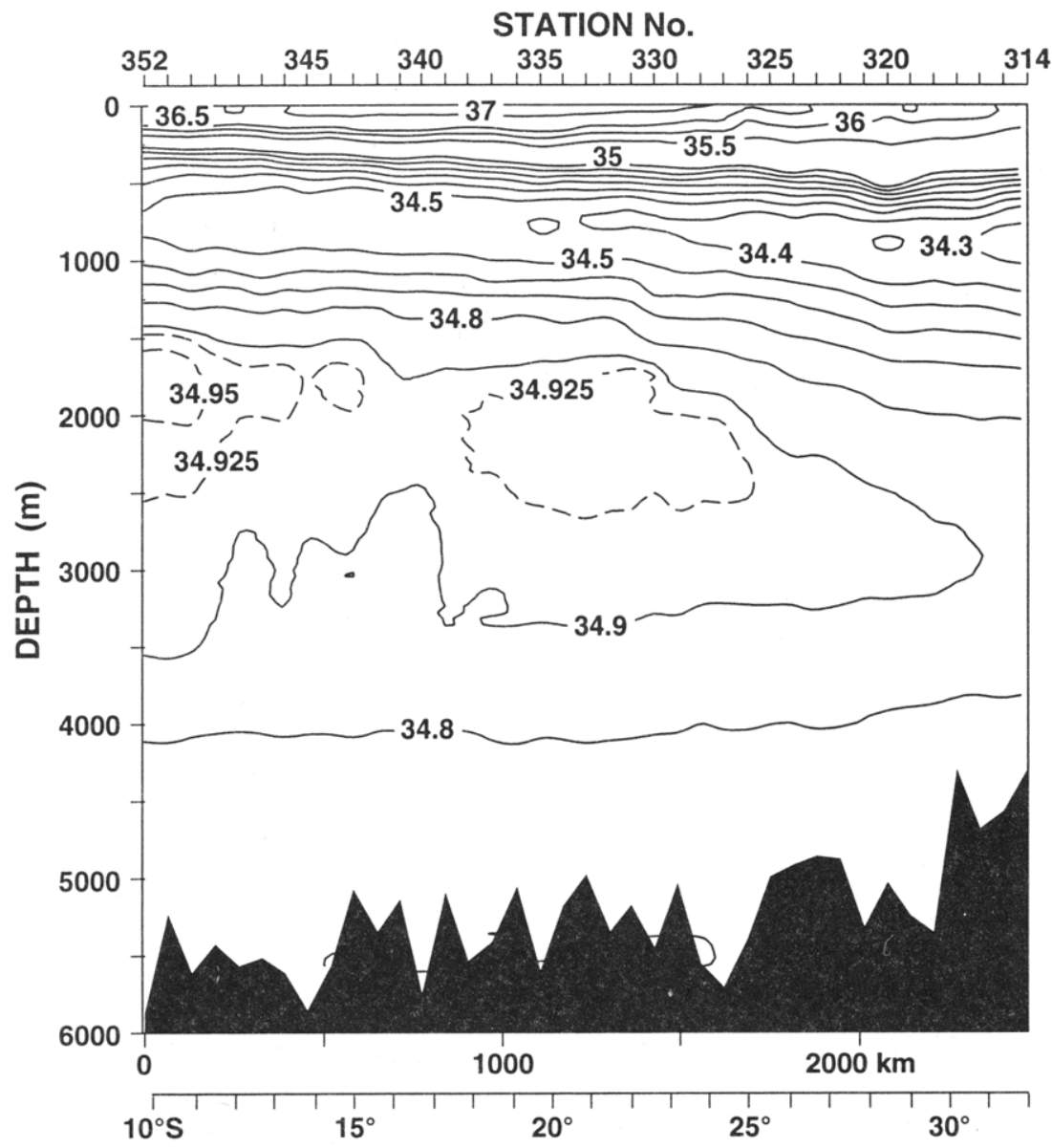

Fig. 3. (a) Profile of salinity (\%) at $25^{\circ} \mathrm{W}$, Melville HYDROS Stas 314-352 in March-April, 1989. (b) Profile of dissolved oxygen concentration $\left(\mathrm{mll}^{-1}\right)$ at $25^{\circ} \mathrm{W}$.

vertical structure occurs all across the South Atlantic (Wüst, 1935; Reid, 1989), though it is weaker east of the Mid-Atlantic Ridge.

The front is due to the eastward flow, and northward excursion, of North Atlantic Deep Water (Fig. 2), which has had its upper layers most strongly modified by lateral and vertical mixing with Circumpolar Deep Water in the southwest South Atlantic. Reid (1989) considers that it is the Circumpolar Deep Water which, after mixing with North Atlantic Deep Water, undergoes this excursion, extending north to $10^{\circ} \mathrm{S}$ before turning east and flowing back south. The point is somewhat a matter of water mass definition and the particular isopycnal or level in question, but again the flow scheme here simply implies that on this isopycnal, more deep water crosses the Mid-Atlantic Ridge before turning north, and that the deep water which does flow north in both the eastern basin and the western basin comes from the western boundary current rather than the Circumpolar Current; that is, the North Atlantic Ocean rather than the Pacific Ocean. 
(b)

\section{HYDROS 4 OXYGEN 500}

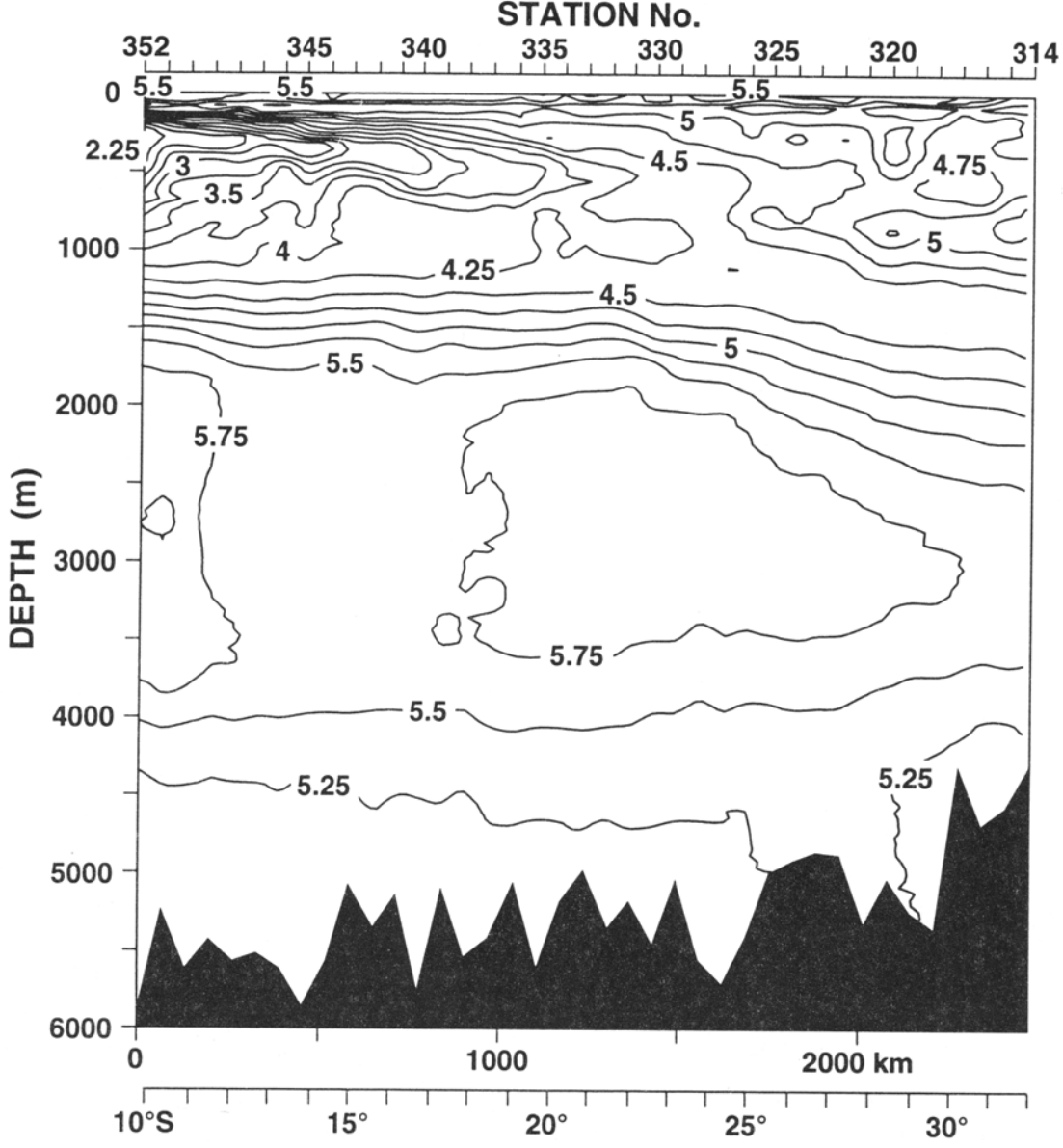

Fig. 3. Continued.

At $25^{\circ} \mathrm{W}$ a maximum in salinity occurs at Sta. $331,22^{\circ} \mathrm{S}$, near $2000 \mathrm{~m}$ depth, within the generally high salinity North Atlantic Deep Water between $20^{\circ} \mathrm{S}$ and $35^{\circ} \mathrm{S}$. Oxygen values are highest near this latitude as well, though the signal is noisier and a single outstanding maximum is difficult to identify. Following Reid (1989), Tsuchiya et al. (1994) explain this structure as the result of anticyclonic flow in the Brazil Basin, carrying high salinity and high oxygen deep water around the basin from the western boundary. Transport calculations at this longitude (Section 5) show zonal flow consistent with anticyclonic motion, but indicate an additional net eastward transport across the salinity maximum.

\section{2. $15^{\circ} \mathrm{W}$}

During Meteor Cruise 15 a short meridional section at $15^{\circ} \mathrm{W}$ was placed just west of the ridge crest, spanning the latitude range of the Namib Col on the Walvis Ridge (Fig. 1). Within this latitude range. the ridge crest is cut by two deep fracture zones near $21^{\circ} \mathrm{S}$ and 
$22^{\circ} \mathrm{S}$ (Heezen and Tharp, 1978) which show up as the deepest points on the $15^{\circ} \mathrm{W}$ section (Fig. 4).

Profiles of potential temperature and salinity (Figs 4a,b) show the three principal deep water masses: the Antarctic Intermediate Water salinity minimum near $800 \mathrm{~m}$ depth, the North Atlantic Deep Water salinity maximum centered at about $2000 \mathrm{~m}$ depth, and the cold, low salinity Antarctic Bottom Water usually defined as water colder than $2^{\circ} \mathrm{C}$. Despite the very limited meridional extent of this section, significant property variations occur within the deep and intermediate water masses. A temperature inversion between these two water masses exists at Stas 168-169, but disappears to the south. On level surfaces or isopycnals in the depth range $1000-2000 \mathrm{~m}$, water generally cools and freshens. A striking exception to this trend is the relatively warm and salty water centered near 2000 $m$ depth at Sta. 172 (close to $22^{\circ} \mathrm{S}$ ). Salinity reaches a maximum greater than 34.93 which is about 0.03 above its surroundings. This salinity maximum is correlated with high oxygen concentration (Fig. 4c). Both of these characteristics indicate purer North Atlantic deep water from the west.

Also at Sta. 172, oxygen concentration attains a maximum value of $5.75 \mathrm{ml} \mathrm{l}^{-1}$. For comparison, Warren and Speer (1991) reported oxygen concentration as high as $5.6 \mathrm{ml} \mathrm{l}^{-1}$ at AJAX Sta. 29 near $1^{\circ} \mathrm{E}$ (Fig. 1) in a similarly isolated maximum. The decrease in oxygen to the east (and that of salinity) is consistent with the schematic circulation field described by Warren and Speer (1991), in which water moving eastward through $15^{\circ} \mathrm{W}$ (see Section $5)$ is absorbed by northward flow above the flank of the ridge. The water supplying the Namib Col Current to the east of the ridge is therefore older, lower oxygen, lower salinity deep water partly from this flank current and partly from the interior of the basin.

\subsection{Namib Col section}

Eight stations were occupied across the Namib Col on the Walvis Ridge near $22^{\circ} \mathrm{S}$ (Fig. 1). Maximum salinity values between 34.90 and 34.91 were found at the saddle (Fig. 5b), agreeing with values found at the same location on GEOSECS Sta. 104 (Bainbridge, 1980). Warren and Speer (1991) noted that at depths greater than $2250 \mathrm{~m}$ high salinity water flowing through the Namib Col was the only possible source for water of similarly high salinity to the east of the Walvis Ridge in the Cape Basin. The relatively strong variation of salinity across the current observed in the AJAX section (and present in the Namib Col section) was explained moreover as a confluence of interior water feeding the current from the north, with somewhat fresher water from the ridge flank current. The same salinity variation persists to the Namib Col itself (Fig. 5b), implying that water from both the interior of the Angola Basin farther north, as well as water from the Mid-Atlantic Ridge, flows through the passage.

Maximum salinity at the Namib $\mathrm{Col}$ is lower than at $15^{\circ} \mathrm{W}$ by about 0.03 , but very close to maximum values on the AJAX section (Warren and Speer, 1991). This supports the idea of essentially continuous zonal flow within the Angola Basin.

Oxygen concentrations (Fig. 5c) reach a maximum at depths near $2200 \mathrm{~m}$ on Sta. 223 and at the bottom on Stas 220-219, at the col itself. The maximum concentration of $5.4-5.5 \mathrm{ml}$ $1^{-1}$ is somewhat less than the 5.5-5.6 $\mathrm{ml}^{-1}$ maximum found on the AJAX section and substantially less than that at $15^{\circ} \mathrm{W}$ (Fig. $4 \mathrm{c}$ ). The explanation for this follows that for salinity: that the Namib Col Current east of the Mid-Atlantic Ridge is fed by older deep water than the current west of the ridge. 
(a)

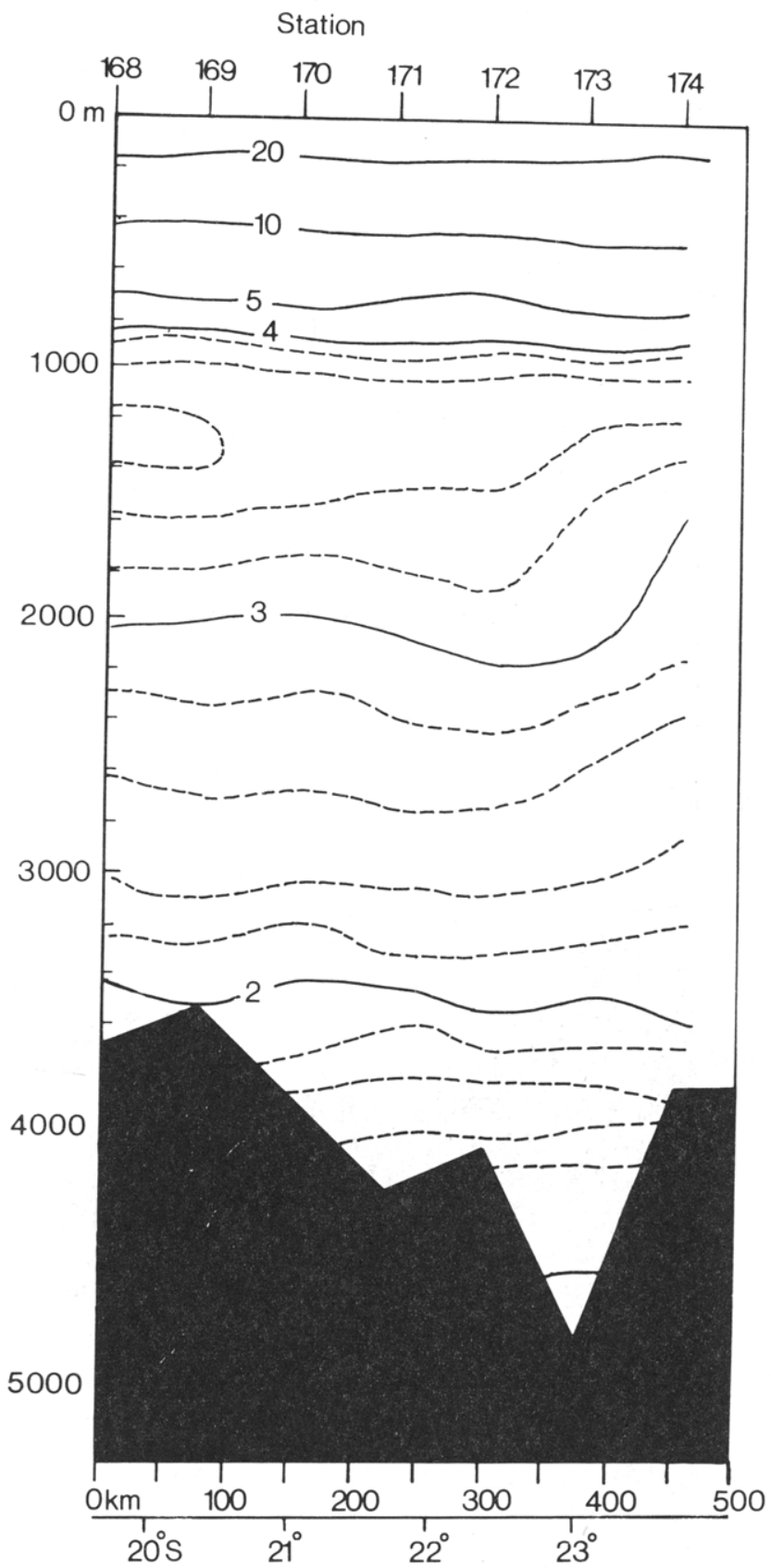

Fig. 4. (a) Profile of potential temperature $\left({ }^{\circ} \mathrm{C}\right)$ at $15^{\circ} \mathrm{W}$ above the western flank of the Mid-Atlantic Ridge as determined by Meteor Cruise 15 Stas 168-174, January-February 1991 (see Fig. 1). Bottom is linearly interpolated between stations. (b) Profile of salinity $(\%)$ at $15^{\circ} \mathrm{W}$. (c) Profile of dissolved oxygen concentation $\left(\mathrm{ml} \mathrm{l}^{-1}\right.$ ) at $15^{\circ} \mathrm{W}$. (d) Profile of potential density

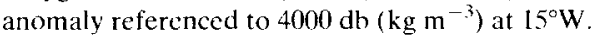


(b)

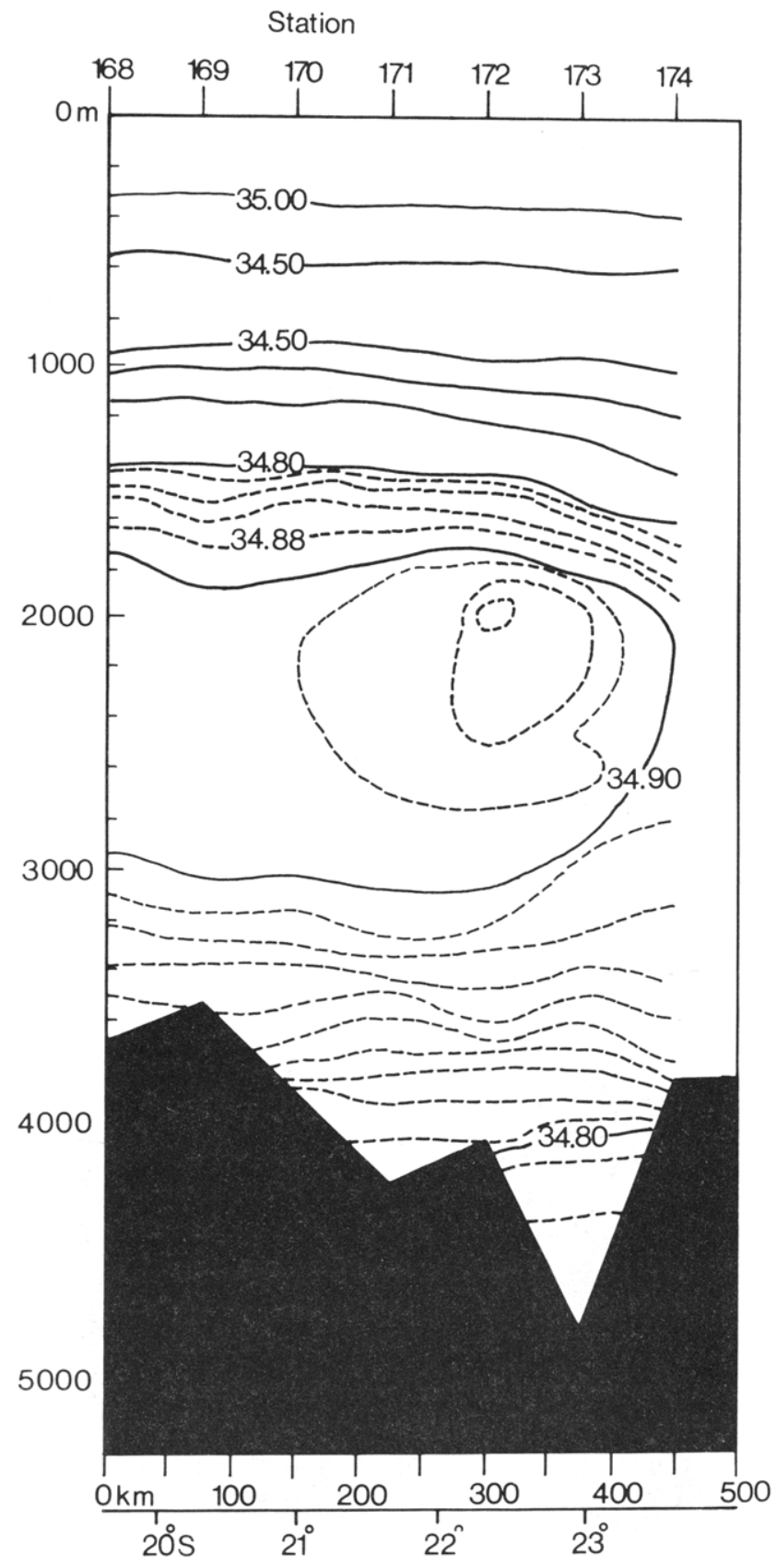

Fig. 4. Continued.

Potential density (Fig. 5d) shows a rather sharp horizontal variation in deep water above the deepest part of the col. A net drop to the south in isopycnal depth across the section signals eastward transport, with a reference level above the bottom-intensified flow (Section 5). 
(c)

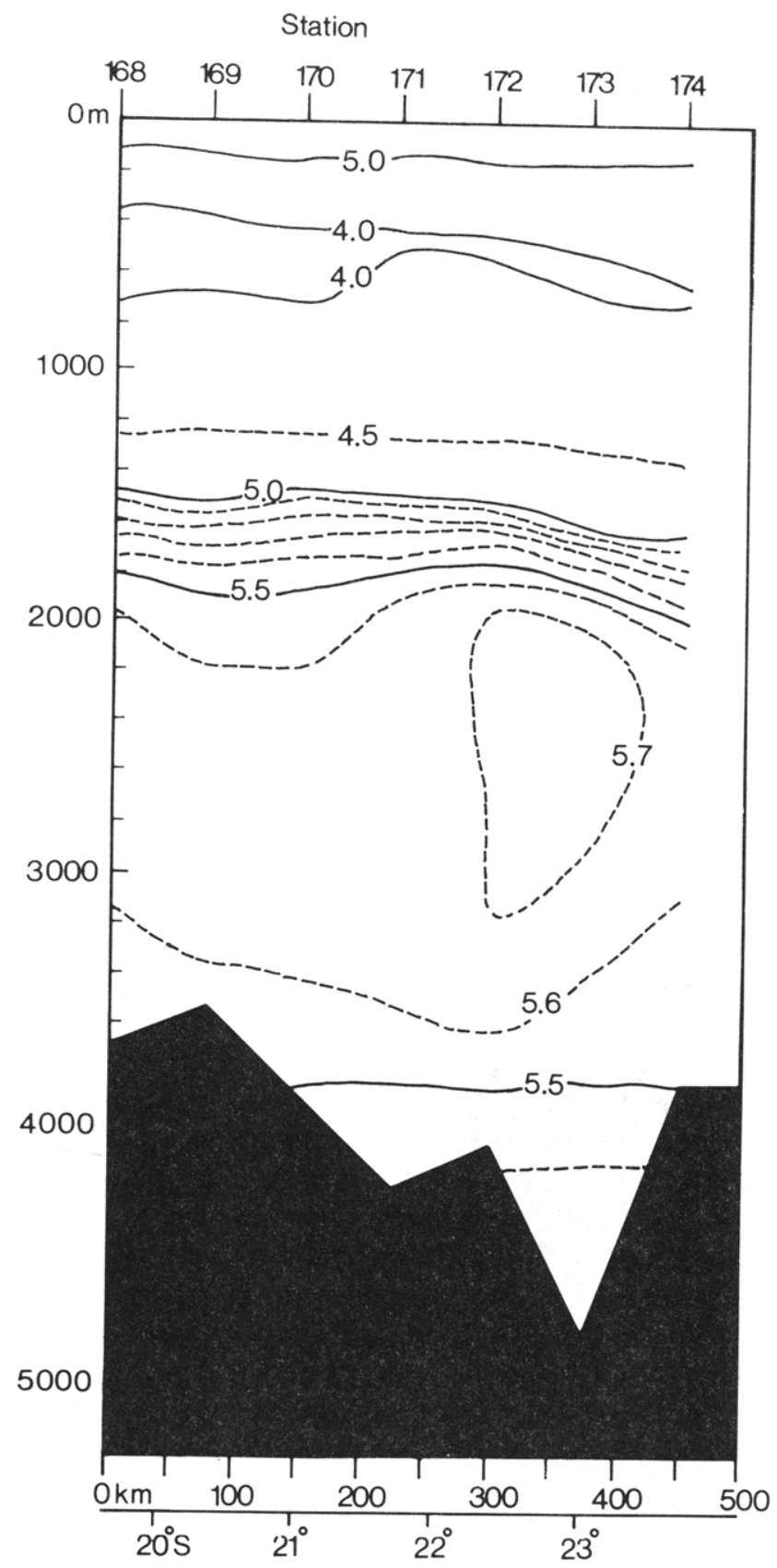

Fig. 4. Continued.

\section{TRANSPORT}

Warren and Speer (1991) used a 1300 dbar reference level to estimate geostrophic transport in the Namib Col Current on the AJAX section in the depth range $1300-3200 \mathrm{~m}$. 
(d)

Station

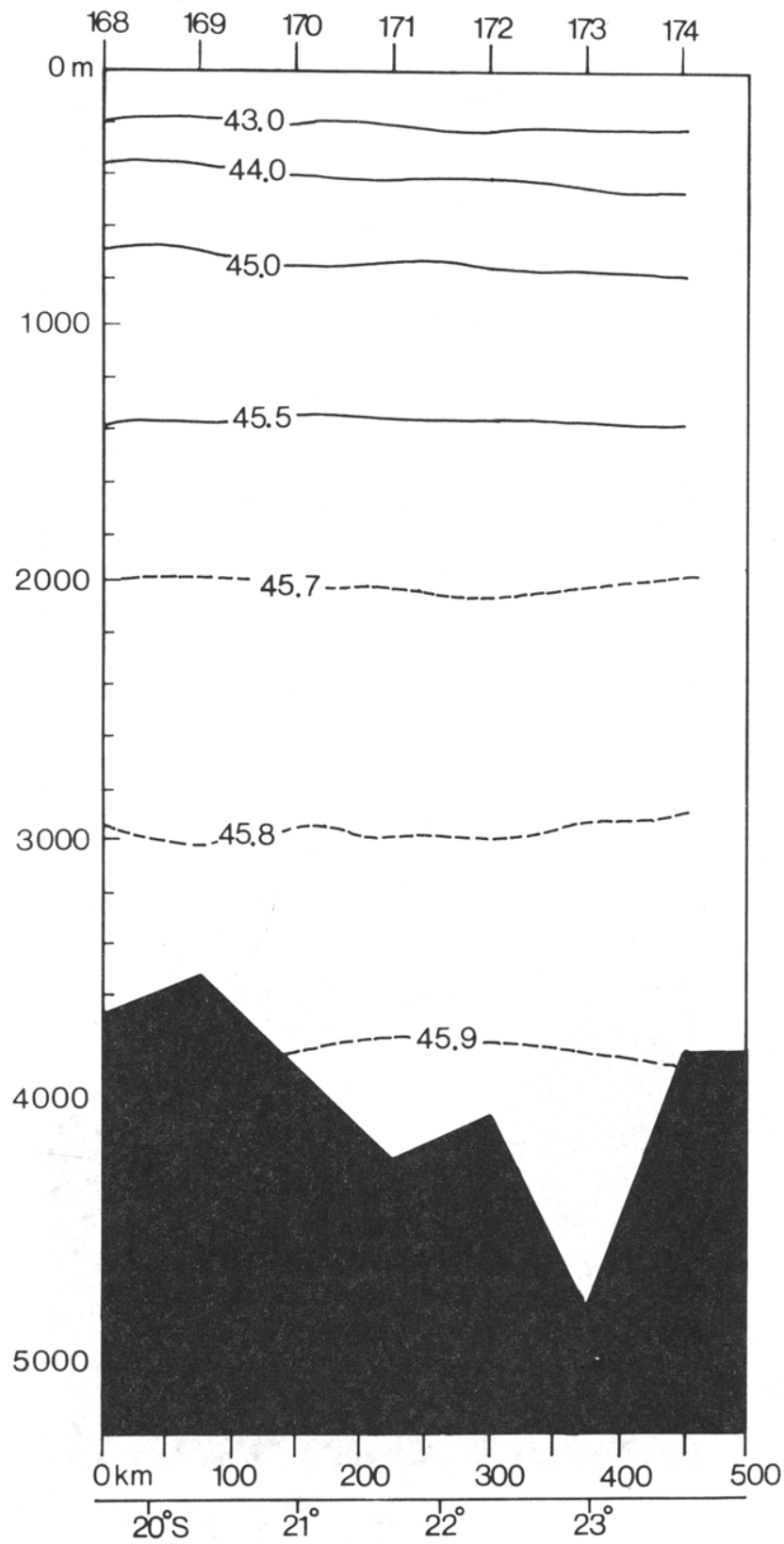

Fig. 4. Continued.

Such a choice is natural in our Namib Col section as it produces eastward flow through the passage. It also gives consistent results at $15^{\circ} \mathrm{W}$ : eastward flow where salinity and oxygen are highest. At $25^{\circ} \mathrm{W}$ the choice is less obvious, but produces equally satisfying results. That is, a general eastward flow from $21-30^{\circ}$ S (Fig. 6), as found by Zhang and Hogg 
(1992), and similar to (but extending somewhat farther north than) Reid (1989). At Lats $19-21^{\circ} \mathrm{S}$ the transport reverses direction. This westward transport is interpreted below as a component of flow "around" the salinity tongue (Fig. 2).

At $15^{\circ} \mathrm{W}$ there is a net eastward transport of $2.2 \times 10^{6} \mathrm{~m}^{3} \mathrm{~s}^{-1}$ in the depth range $1300-3200 \mathrm{~m}$ and station range $170-174$ (Table 1 ). This transport is located mainly above the two fracture zones in the section (Stas 170-171 and 172-173) and corresponds to those stations with the highest salinity. The width of the current as suggested by property fields is about $300 \mathrm{~km}$. Warren and Speer (1991) inferred a broader current, $500 \mathrm{~km}$, in the AJAX section, but also calculated a transport of $2.2 \times 10^{6} \mathrm{~m}^{3} \mathrm{~s}^{-1}$ (Stas 28-33, Fig. 1).

The net eastward transport across the Namib Col is $3 \times 10^{6} \mathrm{~m}^{3} \mathrm{~s}^{-1}$ (Table 1), which fits in with the results at other longitudes. From the southernmost station, 216, the current builds up to nearly $7 \times 10^{6} \mathrm{~m}^{3} \mathrm{~s}^{-1}$ at Sta. 222 , half of which is cancelled by the following station pair 222-223. Considering only those stations covering the main passage, 218-221. the eastward transport is $4.2 \times 10^{6} \mathrm{~m}^{3} \mathrm{~s}^{-1}$.

According to the flow scheme (Fig. 2) deep water flows northeast from the western boundary toward the Mid-Atlantic Ridge, some of which crosses the Rio Grande Rise near $30^{\circ} \mathrm{S}$. Using data from a hydrographic section situated on the rise (Speer and Zenk, 1993), the northward deep water transport offshore of the front to $26^{\circ} \mathrm{W}$ (Fig. 2; their Stas 23-89 with a $2^{\circ} \mathrm{C}$ reference surface) is $6 \times 10^{6} \mathrm{~m}^{3} \mathrm{~s}^{-1}$. Their section lacked horizontal resolution right at the eastern flank of the central Rio Grande Rise (Speer and Zenk, 1993), where an additional $3 \times 10^{6} \mathrm{~m}^{3} \mathrm{~s}^{-1}$ or so may exist, based on extrapolating isopycnal slopes near topography. That leaves $7 \times 10^{6} \mathrm{~m}^{3} \mathrm{~s}^{-1}$ to be supplied from the western boundary north of about $30^{\circ} \mathrm{S}$, in order to explain all of the observed $16 \times 10^{6} \mathrm{~m}^{3} \mathrm{~s}^{-1}$ transport from $21-30^{\circ} \mathrm{S}$ at $25^{\circ} \mathrm{W}$ (Fig. 6). About $2-3 \times 10^{6} \mathrm{~m}^{3} \mathrm{~s}^{-1}$ of this total (across the salinity maximum at $21-23^{\circ} \mathrm{S}$ ) constitutes the Namib Col Current. Taking the $5 \times 10^{6} \mathrm{~m}^{3} \mathrm{~s}^{-1}$ of westward transport between $19^{\circ} \mathrm{S}$ and $21^{\circ} \mathrm{S}\left(\right.$ at $25^{\circ} \mathrm{W}$ ) to represent water expelled to the north of the current, flowing back west and reducing the net eastward transport, about $11 \times 10^{6} \mathrm{~m}^{3} \mathrm{~s}^{-1}$ crosses the Mid-Atlantic Ridge. There it enters and turns north in the ridge flank current $\left(8 \times 10^{6} \mathrm{~m}^{3} \mathrm{~s}^{-1}\right.$ at $24^{\circ} \mathrm{S}$, Warren and Speer, 1991), which subsequently supplies the Namib Col Current and interior flow in the southern Angola Basin.

To make qualitatively the connection between these estimates and the flow scheme, transport along isohalines and across isohalines is crudely distinguished by interpreting the net transport across the core of the salinity maximum as a cross-isohaline component. (In other words, a residual mass transport into an area bounded by a mean isohaline. There could be an eastward salt transport even without a net flow, because of a correlation between velocity and salinity.) Thus, it is the small net transport across the salinity maxima of the western basin meridional sections that is the Namib Col Current west of the MidAtlantic Ridge, and which is marked on the flow scheme by small arrows. Larger transports occur over subsets of station pairs in a sense roughly consistent with flow along isohalines; this is how these larger transports are interpreted, and marked by larger arrows. An origin close to the western boundary between $20^{\circ} \mathrm{S}$ and $23^{\circ} \mathrm{S}$ is consistent with salinity and dissolved oxygen distributions (Fig. 2; Tsuchiya et al., 1994, Fig. 15) and geostrophic shear (Reid, 1989, Figs 26 and 27), but the water entering the Namib Col Current at these latitudes would be replaced by water emanating from the western boundary farther south before it could reach $20^{\circ} \mathrm{W}$. 
(a)

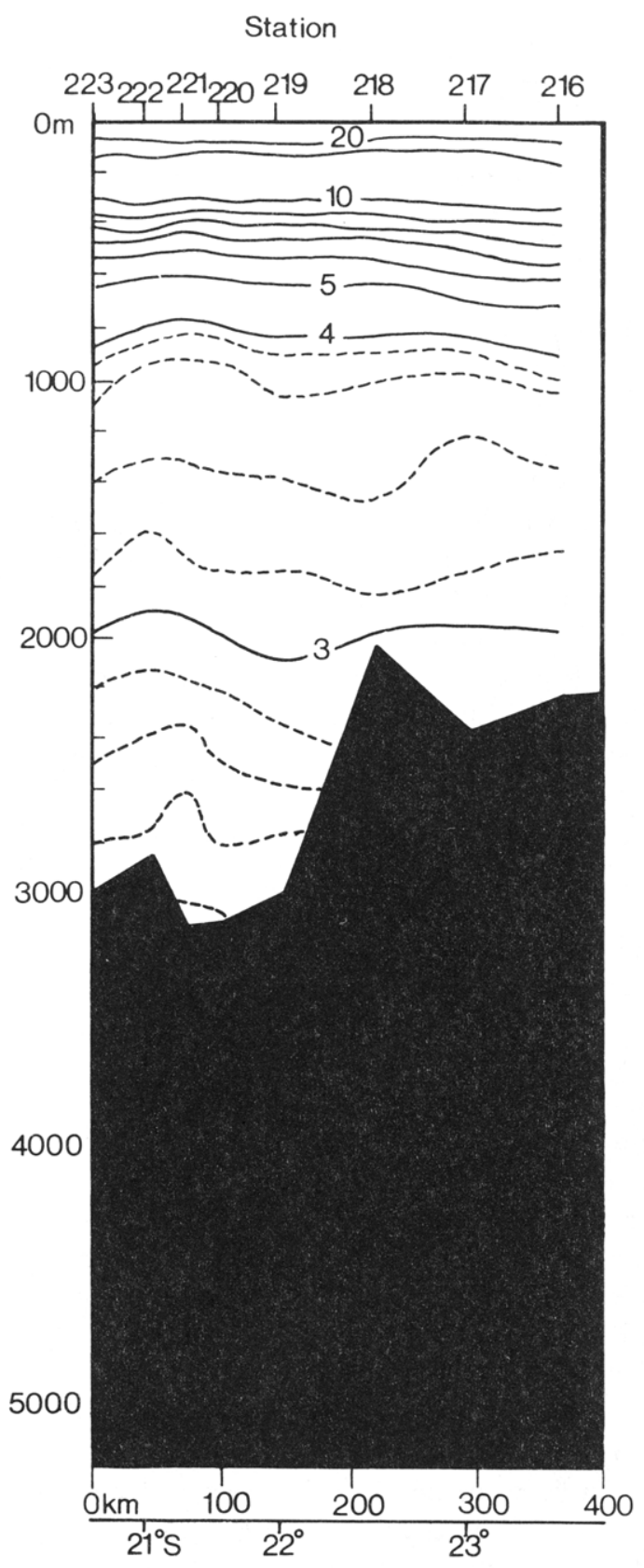

(b)

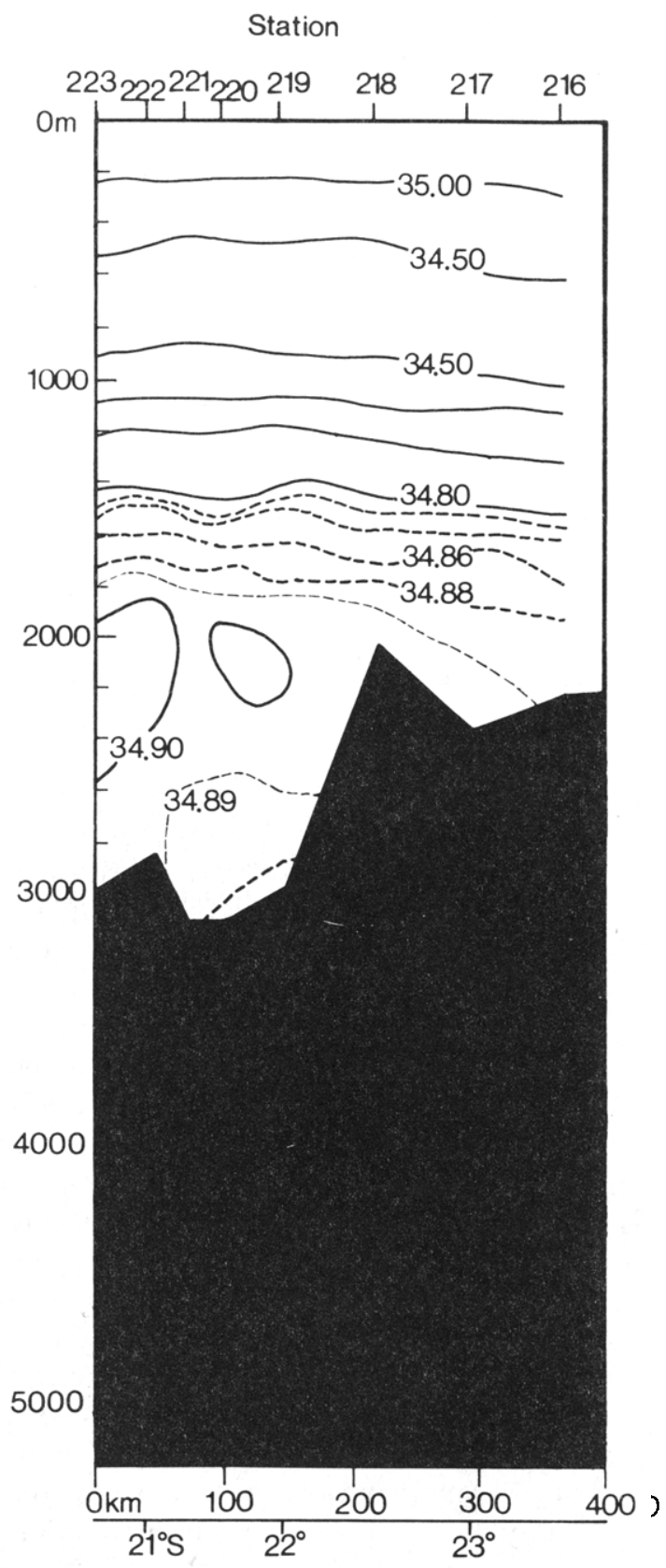

Fig. 5. (a) Profile of potential temperature $\left({ }^{\circ} \mathrm{C}\right)$ at the Namib Col on the Walvis Ridge, Meteor Cruise 15 Stas 216-223 (see Fig. 1). Bottom depth is linearly interpolated between stations. (b) Profile of salinity (\%u) at the Namib Col. (c) Profile of dissolved oxygen concentation $\left(\mathrm{ml}^{-1}\right)$ at the Namib Col. (d) Profile of potential density anomaly referenced to 4000 dt $\left(\mathrm{kg}^{\mathrm{m}} \mathrm{m}^{3}\right)$ at the Namib Col. 
(c)

Station

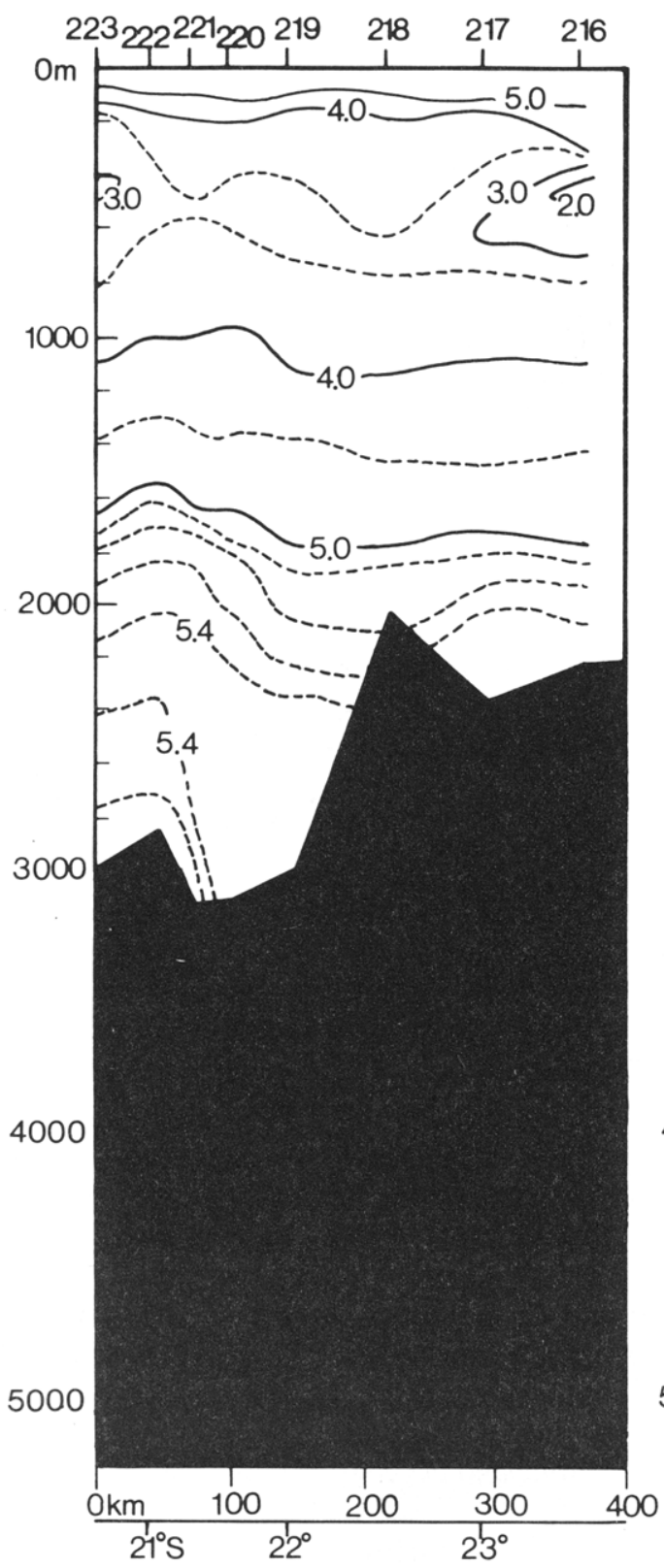

(d)

Station

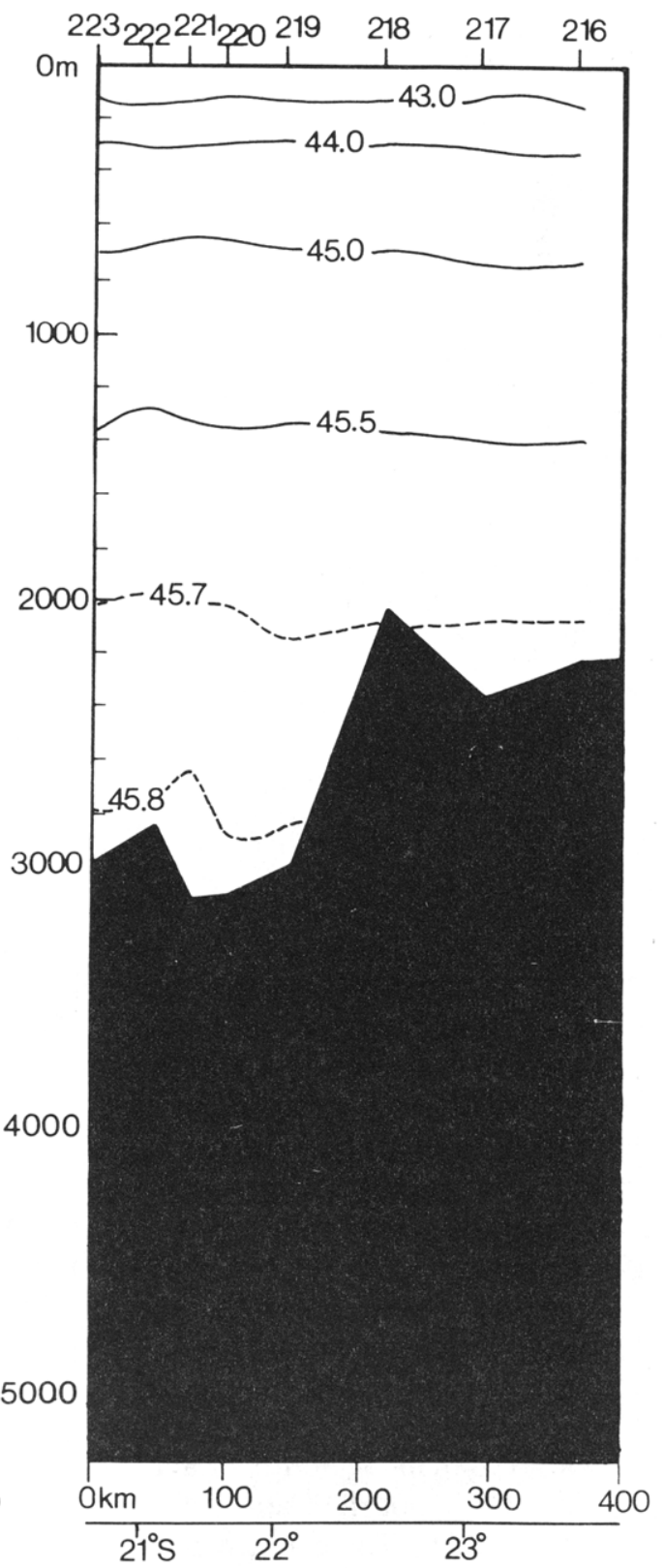

Fig. 5. Continued.

\section{DISCUSSION}

North Atlantic Deep Water as a whole is presumably driveli out of the South Atlantic by the deep inter-ocean density gradient (Gordon et ai.. 1982). Yet a key quostion for the 


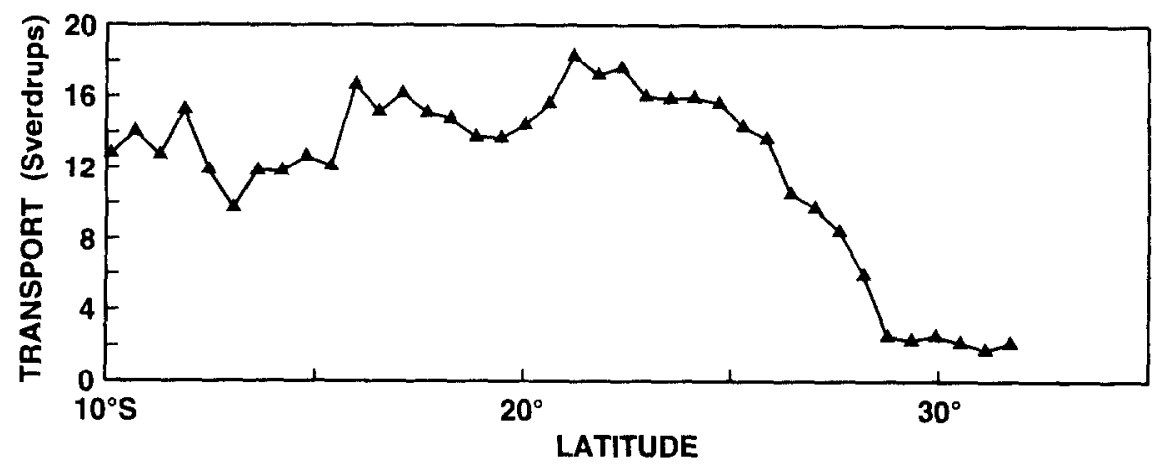

Fig. 6. Geostrophic transport summed cumulatively from south to north at $25^{\circ} \mathrm{W}$, HYDROS Stas 317-350, displayed versus latitude.

Table 1. Volume transports $\left(10^{6} \mathrm{~m}^{3} \mathrm{~s}^{-1}\right)$ by station pair in the interval 1300-3200 $\mathrm{m}$ for Meteor Stas 168-174 at $15^{\circ} \mathrm{W}$ and 216-223 at the Namib Col. These transports are summed cumulatively from south to north in the following row

\begin{tabular}{|c|c|c|c|c|c|c|}
\hline \multicolumn{7}{|c|}{$15^{\circ} \mathrm{W}$} \\
\hline $168-169$ & $169-170$ & \multicolumn{2}{|c|}{$170-171$} & $171-172$ & $172-173$ & $173-174$ \\
\hline 1.7 & -2.9 & \multicolumn{2}{|c|}{1.3} & 0.3 & 0.7 & -0.1 \\
\hline 1.0 & -0.7 & \multicolumn{2}{|c|}{2.2} & 0.9 & 0.6 & -0.1 \\
\hline \multicolumn{7}{|c|}{ Namib Col } \\
\hline $223-222$ & $222-221$ & $221-220$ & $220-219$ & $219-218$ & $218-217$ & $217-216$ \\
\hline-3.9 & 2.1 & 2.3 & 0.3 & 1.6 & 0.1 & 0.5 \\
\hline 3.0 & 6.9 & 4.8 & 2.5 & 2.2 & 0.6 & 0.5 \\
\hline
\end{tabular}

dynamics of this water mass involves the manner in which it leaves this ocean south of Africa. What is the contribution of flow from the northern Cape Basin along its eastern boundary compared to more zonally direct route from the western boundary current off South America? The maximum salinity of water entering the South Atlantic through the Drake Passage is about 34.74 (Gordon et al., 1982), so the higher salinity deep water found east of Africa (Reid, 1989, Fig. 33b; Toole and Warren, 1993) must be North Atlantic Deep Water carried there by eastward flow below the Subtropical Front (Whitworth and Nowlin, 1987), in the South Atlantic Current (Stramma and Peterson, 1990), or flow down the eastern side of the Cape Basin. Both options were described by Gordon et al. (1992) and discussed by Toole and Warren (1993), and both were thought likely to be delivering North Atlantic Deep Water to the southwest Indian Ocean. The latter may be guided by the Agulhas Current and Agulhas Return Current to nearby basins, while the former would, if it does not turn back into the South Atlantic, supply deep water to the Indian Ocean directly from the western boundary current near $40^{\circ} \mathrm{S}$.

The existence of southward flow near the boundary is illustrated by its impact on dissolved oxygen, phosphate, and silica distributions near $2200 \mathrm{~m}$ depth (Reid, 1989, Fig. 
32), which imply a northern Cape Basin origin for the deep water rounding the southern tip of Africa. In a box model of the Indian Ocean circulation, Metzl et al. (1990) emphasized the role of oxygen and nutrient fluxes in setting an $11 \times 10^{6} \mathrm{~m}^{3} \mathrm{~s}^{-1}$ deep water inflow to the Indian ocean in their box nearest the African continent, when they included biological sources in their model.

That a significant fraction of the North Atlantic Deep Water outflow might occur via the eastern Cape Basin route seems surprising, but is suggested by recent flow calculations. Reid (1989, Fig. 23) has roughly one third of the deep water flow (2500 db) of salinity greater than $34.8 \%$ in the eastern boundary region of the Cape Basin (at $3000 \mathrm{db}$ the fraction near the continent is even higher). Some evidence for a significant eastern boundary current comes from direct current meter measurements of a deep southward motion for a period of several months on the eastern boundary near $30^{\circ} \mathrm{S}$ (Nelson, 1989). Saunders and King (1995) incorporated this evidence into their solution for total flow near this latitude, and inferred a southward transport of about $7 \times 10^{6} \mathrm{~m}^{3} \mathrm{~s}^{-1}$ in the deep water $(1500-4000 \mathrm{~m})$ concentrated east of $10^{\circ} \mathrm{E}$. The amount of North Atlantic Deep Water flowing east near $40^{\circ} \mathrm{S}$ and continuing into the Indian Ocean is not yet completely clear, but Saunders and King (1995) calculated a further deep water transport of about $15 \times 10^{6} \mathrm{~m}^{3}$ $s^{-1}$ across Lats $35-45^{\circ} \mathrm{S}$ on their diagonal section above the eastern flank of the Mid-Atlantic Ridge $\left(15^{\circ} \mathrm{W}-5^{\circ} \mathrm{E}\right)$. Over the rest of the section from the ridge crest to the western boundary the net deep water transport was zero.

The role of the Namib Col Current as a source of deep water to the northern Cape Basin is clear, and the ultimate connection of this source to flow around the southern tip of Africa seems probable. Adding together the tranport of this current and a comparable southward interior flow component (as observed at $24^{\circ} \mathrm{S}$; Warren and Speer, 1991), the total $\left(5 \times 10^{\circ}\right.$ $\mathrm{m}^{3} \mathrm{~s}^{-1}$ ) may be enough to explain the apparently large contribution of the eastern Cape Basin deep water route.

With a transport of roughly $3 \times 10^{6} \mathrm{~m}^{3} \mathrm{~s}^{-1}$, the Namib Col Current barely rises above uncertainties associated with deep transient motion. Nonetheless, the measurements reported here give a consistent picture of a transatlantic eastward current correlated with tracers over a wide span of time, supporting a mean flow interpretation. Water mass contributions from the north and south change the water mass properties of the current along its route. Despite the relative weakness of this current compared to the major South Atlantic deep western boundary currents, it manages to have an important impact on the large-scale property distributions in the deep water. This fits its role as a pathway for North Atlantic Deep Water to cross and eventually leave the South Atlantic Ocean south of Africa.

Acknowledgements-Support for the Meteor observations came from the Dcutsche Forschung Gemeinshaft grant Si 111/38-1 to G. Siedler and the Bundesministerium Für Forschung und Technologic WOCE project 03F0525A. Further support came from the Centre National de la Recherche Scientifique (KGS) and NSF grants OCE86-14486 and OCE 92-01315 (LT). We would like to thank M. Tsuchiya for helpful comment and J. Holfort for dat a processing.

\section{REFERENCES}

AJAX Expedition (1985) Physical, chemical, and in situ CTD data from the AJAX Expedition in the South Atlantic Ocean. SIO Reference 85-24 and TAMU Reference 85-4-D. Scripps Institute of Oceanography and Texas A. \& M. University, $275 \mathrm{pp}$. Unpublished data report. 
Bainbridge A. E. (1980) GEOSECS Atlantic Expedition: Vol 2 Sections and profiles. National Science Foundation, Washington, D.C., U.S.A., 121 pp.

Defant A. (1941) Quantitative Untersuchunden zur Statik und Dynamik des Atlantischen Ozeans. Die absolute Topographie des physikalischen Meeresniveaus und der Druckflachen sowie die Wasserbewegungen im Raum des Atlantischen Ozeans. InL Wissenschaftliche Ergebnisse der Deutschen Atlantischen Expedition auf dem Forschungs und Vermessungsschiff "Meteror" 1925-1927. 6:2nd Part, 1, pp. 191-260.

Gordon A. L., E. J. Molinelli and T. N. Baker (1982) Southern Ocean Atlas. Columbia University Press, New York, $34 \mathrm{pp}$.

Gordon A. L., R. F. Weiss, W. M. Smethie and M. J. Warner (1992) Thermocline and intermediate water communication between the South Atlantic and Indian Oceans. Journal Geophysical Research, 97, 72237240 .

Heezen B. C. and M. Tharp (1978) General Bathymetric Chart of the Oceans (GEBCO). Sheet 5. 12. Canadian Hydrographic Service, Ottawa.

HYDROS (1992) Physical, chemical and CTD data, R.V. Melville, 13 March-19 April 1989. Ocean Data Facility, Scripps Institute of Ocean., University of California, San Diego, $190 \mathrm{pp}$.

McCartney M. S., S. L. Bennett and M. E. Woodgate-Jones (1991) Eastward flow through the Mid-Atlantic Ridge at $11^{\circ} \mathrm{N}$ and its influence on the abyss of the eastern basin. Journal of Physical Oceanography, 21, $1089-1121$.

Metzl N., B. Moore and A. Poisson (1990) Resolving the intermediate and deep advective flows in the Indian Occan by using temperature, salinity, oxygen and phosphate data: the interplay of biogeochemical and geophysical traccrs. In: Geochemical variability in the oceans, ice, and sediments, L. P. Labeyrie and C. Jeandel, Editors, Palacogeography, Palaeoclimatology, Palacoecology (Global Planetary Change Section), $89,81-111$.

Nelson G. (1989) Poleward motion in the Benguela area. In: Poleward flows along eastern ocean boundaries, S.J Neshbya, Ch. N. K. Mooers, R. L. Smith and R. T. Barber, Editors, Springer-Verlag, New York. pp. 110130 .

Reid J. (1989) On the total geostrophic circulation of the South Atlantic Ocean: flow patterns, tracers, and transports. Progress in Oceanography. 23, 149-244.

Saunders P. M. and B. A. King (1995) Oceanic fluxes on the WOCE All scction. Journal of Physical Oceanography, 25, 1942-1958.

Sicdler G. and W. Zenk (1992) WOCE S̈udatlantik 1991. Reise Nr. 15, 30 Dezember 1990-23 März 1991. Meteor-Berichte Universität Hamburg, 92-1, $126 \mathrm{pp}$.

Speer K. and W. Zenk (1993) The flow of Antarctic Bottom Water into the Brazil Basin. Journal of Physical Oceanography, 12, 2667-2682.

Stramma L. and R. G. Peterson (1990) The South Atlantic Current. Journal of Physical Oceanography. 20. 846859.

Toole J. M. and B. A. Warren (1993) A hydrographic section across the subtropical South Indian Ocean. DeepSea Research. 40, 1973-2019.

Tsuchiya M., L. D. Talley and M. S. McCartney (1994) Water-mass distributions in the western South Atlantic; A section from South Georgia Island $\left(54^{\circ} \mathrm{S}\right)$ northward across the equator. Journal of Marine Research, 52 , $55-81$.

Warren B. A. (1982) The deep water of the Central Indian Basin. Journal of Marine Research, 40 (Suppl.), 823860.

Warren B. A. and W. B. Owens (1988) Decp currents in the central subarctic Pacific Ocean. Journal of Physical Oceanography, 18.529-551.

Warren B. A. and K. G. Speer (1991) Deep circulation in the eastern South Atlantic Ocean. Deep-Sea Research, 38 (Suppl.), S281-S322.

Whitworth T. III and W. D. Nowlin. Jr (1987) Water masses and currents of the Southern Ocean at the Greenwich Meridian. Journal of Physical Oceanography. 92, 6462-6476.

Wüst G. (1935) Schichtung und Zirkulation des Atlantischen Ozcans. Dic Stratosphäre. In: Wissenschaftiche ergebnisse der deutschen atlantische'n expedition auf dem forschungs- und vermessungsschiff "Meteor" 19251927. 6:1st Part, 2. $180 \mathrm{pp}$. (The' Stratosphere of the Atlantic ocean. W. J. Emery, editor. 1978, Amerind, New Delhi, 112 pp.)

Zhang, H-M. and N. G. Hogg (1992) Circulation and water mass balance in the Brazil Basin. Joturnal of Marine Rescarch, 50, 385 420. 